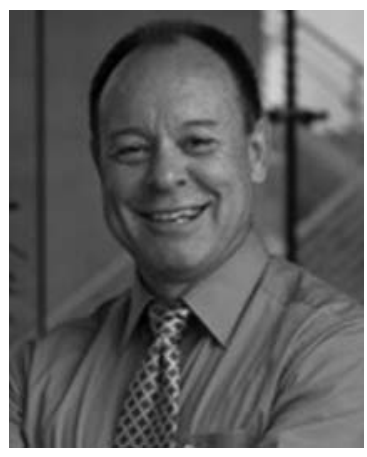

\title{
A Conversation with Luis Parada
}

\author{
INTERVIEWER: JAN WITKOWSKI \\ Executive Director, Banbury Center at Cold Spring Harbor Laboratory
}

Luis Parada is the Director of the Brain Tumor Center, the Albert C. Foster Chair, and an American Cancer Society Research Professor at Memorial Sloan Kettering Cancer Center.

Jan Witkowski: You were a second-year graduate student when you first started working on cancer genes. Did you have any sense of what that would lead to?

Dr. Parada: I wasn't clairvoyant about the future, but the excitement was absolute and instantaneous. As a first-year graduate student at MIT, we didn't rotate through laboratories the way most graduate programs work. Instead, we took course work and then we listened to seminars from the faculty. When an assistant professor named Robert Weinberg got up and said, "We can take DNA from tumor cells and put it into normal cells and they become tumorigenic, and then we can take the DNA and first clip it with one restriction enzyme and retain tumorigenic properties, but when we clip with another enzyme it loses its tumorigenic capacity." I realized, "It's a gene. Cancer is a gene." At that moment, I committed to work with Robert Weinberg. It was the best decision I ever made in my career. Of course, it was rudimentary molecular biology. We had to purify our own restriction enzymes before New England BioLabs started selling them. The primary technique we used was the Southern blot, which again, I think is now a thing of the past. However, the Southern blot permitted us, for the first time, to visualize genomic pieces of DNA. It was the key to my central project as a Ph.D. student, which was to determine if the transforming genes we saw in human cells were related to the oncogenes that were resident in retroviruses that were the heart of the cancer field at that time, if these were innate tumor genes that caused cancer. The answer was, resoundingly, yes.

Jan Witkowski: The other noteworthy thing about that 1982 paper is that there's not a single DNA sequence in it.

Dr. Parada: Nope. The sequence of the amino acid 12 mutation in ras was the sequel, performed by my good friend and colleague Cliff Tabin. He sequenced, maybe, 1000 bases, and even that required a collaboration. We couldn't do it all by ourselves.
Jan Witkowski: There was a bit of a race on at the time, wasn't there? There was Mike Wigler's group. There were Geoff Cooper and Mariano Barbacid.

Dr. Parada: We were aware of Geoff Cooper's work, which was orthogonal to ours, in that he wasn't seeing the same things that we were seeing. We were aware of Mike Wigler's work because Mitch Goldfarb was a Bob Weinberg graduate student who did postdoc work with Mike Wigler at the Cold Spring Harbor Laboratories and pursued the same line of inquiry. We weren't aware of Barbacid's work until it came out, so we weren't in discussion with him at the time. It was a funny race, in the sense that we didn't know the answer. It wasn't like the race to, for example, identify the structure of DNA where we knew that there had to be a structure to be identified and we were going to find it. It was more like, once we realized that there was such a thing, we were all trying to figure out how to clone cancer genes.

Jan Witkowski: More recently, you've been working on glioblastomas. One of your key findings is that glioblastomas don't arise through glial cells, but rather through a special set of neural stem cells.

Dr. Parada: Correct. As someone who has always been interested in the developmental biology aspects of disease and the natural history of how tumors evolve, I've been frustrated that so many textbooks claim to tell us where and how cancer arises. There has actually been very little, if any, direct investigation into the origins of cancer. The only really important work of that sort has been done on how hematopoietic stem cells are the root of leukemias. In solid tumors, the origins are really uncharted territory, at least until the last few years. I've spent many years studying the development of the brain and the nervous system, so we decided to tackle the problem in tumors of the nervous system. We generated genetically engineered mouse models that harbored the mutations that were found most frequently in sporadic glioblastoma, an incurable tumor of the brain in humans. We discovered that

(C) 2016 Parada. This article is distributed under the terms of the Creative Commons Attribution-NonCommercial License, which permits reuse and redistribution, except for commercial purposes, provided that the original author and source are credited. 
when we mutated the genes in the stem cells of the brain, $100 \%$ of the mice developed glioblastomas that the neuropathologists at the hospital could not distinguish from the human disease. If we mutated the genes in any other cell in the brain, we never got glioblastoma. We concluded that this is a disease of stem cells, and that - analogous to what is known in many hematopoietic cancers- the mutations actually accumulate in the stem cells. The disease manifests in a cell in a way that resembles some normal product of the stem cell, but that's just, if you will, the "dressing"; it's not the source, the core. The core is actually that there's a unique and important property of stem cells that we refer to as "self-renewal". Selfrenewal means that these cells are immortal. As long as we're alive, thankfully, we have stem cells in our brain and in our blood that we need. The analogy to cancer cells is that they also are immortal.

Jan Witkowski: Does that imply that the standard treatments of chemotherapy and radiation aimed at the bulk of the tumor are really misdirected, that what you need to target is just a small number of stem cells?

Dr. Parada: That's a key implication. Chemo- and radiotherapies are designed, on purpose, to kill proliferating cells, cells that divide aggressively. The consequence is that anticancer therapies are not really anticancer therapies. They don't distinguish between a cancer cell and a normal cell; they distinguish between a dividing cell and a nondividing cell. That's why you get all the terrible side effects of chemotherapy: we lose our hair, become anemic, develop gastrointestinal problems. Interestingly, when the chemotherapy is removed, our hair grows back, our blood comes back, and our digestive problems go away. Why? Because the chemotherapy, in addition to targeting the proliferating cells in the tumor, also targets the proliferating cells in our normal stem cell compartments but not the stem cells themselves. That's why we can grow our hair back, and why we recover from anemia, but it's also why the tumors come back: The stem cells were never touched by the therapy.
Jan Witkowski: Are there examples from other solid tumors of these sorts of system?

Dr. Parada: There are emergent examples. There are several groups that have taken the same developmental biology approaches that we have. In my view, they've demonstrated convincingly the stem cell of origin for skin cancer and for colon cancer. There is very good evidence for cancers of the liver and the bladder as being stem-cell-of-origin cancers and moreover, having a cancer stem cell as the driving force in this hierarchical tumor growth, which was really something that was not appreciated until recently.

Jan Witkowski: Does your research provide clues as to what the target in stem cells might be?

Dr. Parada: It does. I cannot emphasize enough how important it was to realize that there is such a thing as a cancer stem cell and that there is a hierarchical method of tumor growth, because we now understand who the enemy is. You have to understand the enemy to isolate it, and then target it. We can do this now with glioblastoma. Our research team is making great advances and we have what we believe are promising strategies that directly target the cancer stem cell and not normal dividing cells.

Jan Witkowski: Do stem cells have particular molecular characteristics that could be used?

Dr. Parada: Yes and no. There are certain common denominator properties held within all stem cells (e.g., embryonic, blood, skin, etc.) that also are found in cancer stem cells. That's not what we want to target, though. When I cure your tumor, I don't want to kill all of your hematopoietic stem cells. Those common denominators are not ideal targets. However, similar to what is seen in the hematopoietic system, cancer stem cells do acquire certain properties that are unique. They are stem cells on steroids, if you will. We have to target the steroids, and conceptually, that's doable. 


\section{$\$_{\text {CSH\& }}^{\infty}$ Cold Spring Harbor Symposia SYMPOSIA On Quantitative Biology}

\section{A Conversation with Luis Parada}

Cold Spring Harb Symp Quant Biol 2016 81: 336-337 originally published online April 10, 2017 Access the most recent version at doi:10.1101/sqb.2016.81.032565

Creative This article is distributed under the terms of the

Commons http://creativecommons.org/licenses/by-nc/4.0/, which permits reuse and

License redistribution, except for commercial purposes, provided that the original author and source are credited.

Email Alerting Receive free email alerts when new articles cite this article - sign up in Service the box at the top right corner of the article or click here. 